\title{
An Analysis of Safety Practices of Farmers in Odisha (India) for Sustainable Agriculture
}

\author{
Debesh Mishra, KIIT University (Deemed), India \\ (iD) https://orcid.org/0000-0003-2665-1365 \\ Hullash Chauhan, KIIT University (Deemed), India \\ Ashok Kumar Sahoo, School of Mechanical Engineering, KIIT University (Deemed), India
}

\begin{abstract}
An in-depth review of literature was done in this study which was further followed by consultation and discussion with experts and farmers in the agricultural sectors of Odisha (India) in view of the adoptability perception and behaviours of farmers towards the health and safety practices. Then, a strengths, weaknesses, opportunities, and threats (SWOT) analysis was employed in order to evaluate the current agricultural safety practices by the farmers and its impact for a sustainable agriculture. Further, on the basis of the data and information obtained from the farmers as well as the experts, the major barriers in context with the sustainability indicators (social, environmental, and economic) for the adoption of health and safety practices were obtained followed by the use of the Fuzzy-COPRAS method to rank the barriers in order of their preferences.
\end{abstract}

\section{KEYWORDS}

Agriculture, Barriers, Fuzzy-COPRAS, Odisha, Safety Practices, SWOT

\section{INTRODUCTION}

There has been a growing demand for sustainable agriculture in response to the ill-hazards due to agricultural practices. Although, a number of health and safety practices have been developed to protect the farmers from the adverse impacts in agricultural sectors, bur because of some constraints as well as barriers, the practices are still found of unused by many of the agricultural workers. One of the major goals of sustainable agricultural systems is decreasing the ill-hazards in agriculture. A good agricultural safety practice is one approach which deals with these issues including the protection of human-health and the environment. Moreover, a number of side effects from the use of syntheticfertilizers and other agro-chemicals have been found to be utilized in the agricultural sectors in India. Thus, there is a need to address the present issues related to the safety practices in the agricultural sectors. In order to achieve sustainable agriculture, an appropriate consideration to the economic, environmental as well as social factors in the agricultural sectors in India need to be provided and this is achievable through proper and adequate health $\&$ safety practices in all aspects of faming. The 
purpose of this study was to investigate the major barriers to application of good agricultural safety practices in the agricultural sectors of Odisha in India for its sustainability.

A number of studies have been carried-out regarding the uses of personal protective equipments and devices as well as on the ill-hazards with regard to the agricultural sectors. For instance, the agro-chemicals utilization was adopted in order to deal with the issues of deficient food-supplies to meet the ever growing population needs in the nation. A number of side effects have been recorded from the use of synthetic fertilizers as well as other agro-chemicals that usually cause water-pollution as a result of leaching and washing away of such agro-chemicals in rivers by erosions (Smil, 2001). It has been revealed by different studies that by the sustainable agriculture, through various initiatives the present as well as future food-demands can be fulfilled (DFID, 2004; FAO, 2013; Godfray et al., 2010; Oyo and Kalema, 2016). For example, the initiatives were as follows: tillage-reductions (Lal, 1991), crops-rotations (Caporali and Onnis, 1992), managing irrigations (Tilman et al., 2002), integral management of pests (Gurr et al., 2003), nutrients-management, enhancement of wild-habitats, genetic-resistance enhancements, farm-enterprises diversifications, and community-wellbeing improvements (Jackson-Smith, 2010). Geer et al. (2006) have revealed of a higher risk perception of workers owing to a poor-fit $\&$ frequency of replacement of personal protective equipment, and crosscontamination by workforce moving into working-zones. In addition to the normal farm level risks, the adolescents may face greater risks by avoiding the use of personal protective equipment or having lack of access to protective machineries. Therefore, the adolescents and their parents should be advised by the health-care providers regarding reduction of risks, and mainly on the personal protective equipment utilizations (Reed et al., 2006). It was suggested to support farmers to invest in physicalsafety on the farm and there was a need of evidences of any safety intervention to be a sound healthmanagement as well as economic-investment choice. The farmers were found of neglecting the wear of their hearing protections, due to inconveniences, discomforts as these created new hazards by restricting communication with others (Gates and Jones, 2007; McCullagh and Robertson, 2009). However, Kaustell et al. (2011) have stated that the indications of long-lasting or effectiveness are limited within the literature for such interventions. Organic farming is a multi-functional system that reduces the economic, environmental as well as social functions. Through organic farming the multifunctional benefits include contribution to livelihood improvements, food-security, flexibility to climate-changes, increasing in long run yields, minimizing financial-risks, market-opportunities creation, developing health as well as the environment, hostility to desertification among other several advantages (IFOAM, 2007). MacFarlane et al. (2008) have reported of 10-40\% of farmers usually of not at all using personal protective equipment. Kaustell et al. (2011) have used a collaborative interpretation method and farm interviews for identifying factors affecting the adoption as well as implementation of safety information. The three major barriers were found as personal farmers' characteristics, limited resources for safety-improvements, and slower incremental-evolution of the physical farm-environment with older \& hazardous environments remaining along with latest \& safer improvements. The agro-based industrial sectors have significant role in the financial system to foster on food-security and basic-needs of human-beings. The occurrence of financial worries and stressed on the farm was associated with the safety assessments made by farmers in Canada (Hagel et al., 2013).Agribusiness has environmental impacts because of land-clearing, leaving-space discontinuities, biological-communities change, soil-disintegration, desertification, eutrophication, and biodiversitylosses (Conway and Barbier, 2013; Fan et al., 2012). The ecosystems get contaminated (Conway and Pretty, 2013; Diaz and Rosenberg, 2008) and human-health gets affected by the use of agrochemicals (WHO, 1996) that include fertilizers and pesticides. Similarly, the agricultural sectors are subjected to adverse environmental-changes with respect to its degree and productivity throughout the world (Battisti and Naylor, 2009; Turral et al., 2011). Sustainability primarily includes an incorporated and a far reaching way for the well-being to deal with environmental, social, and economic process (Sathaye et al., 2007; Tracey and Anne, 2008) and it requires the support of various stakeholders and point-of-views to build up an advancement through a shared activity-plan (Kates et al., 2005). In 
order to think about monetary improvement, there was a simultaneous combination of the preservation and rebuilding of the indigenous environment and empowerment in social-values, with the integration of "Environment, Equity and Economy" into a sustainability-model (Daly, 1990). Sustainability in agriculture has a major impact on food-production, and because of persistent use of natural-resources and environmental-effects, it has been a central-concern (Bell and Morse, 2008). The development of sustainable agriculture concern was first focused on the environmental-factors which was further included with social, political and economic factors (DFID, 2003). The economic, social and environmental issues were reported of included in agricultural sustainability (GIZ, 2012; JacksonSmith, 2010). The capacity of farmers for producing sufficient-foods to feed themselves, their communities, and to maintain the economic-viability of agriculture were included in economic sustainability (Jackson-Smith, 2010; Van Calker, 2008). Social sustainability included the equity along with the quality farmers' life as well as the consumers and members of the community. However, the enhancement of the environment-quality of the landscape and natural-resource bases were included in the environmental sustainability (Sydorovych and Wossink, 2007; Jackson-Smith, 2010). Social, economic and environmental "system of systems (SOS)" was reported to represent the agriculturalsystems (Francis et al., 2003). With the improvement \& protection of the social, economic and environmental systems of agriculture in a cyclic manner, the agricultural-system can be sustainable. Thus, in order to achieve this, a vigorous system for balancing and to synergize the trade-offs between SOS was suggested to be indispensable (Jackson-Smith, 2010). For resolving the interpretation complexities and to apply agricultural sustainability from local to global levels at different scales with improved consideration of social, economic and ecological flexibilities in agricultural-systems, an efficient and ample evaluation method would be useful. The sustainability assessment was revealed to be relied on human \& ecological well-being in order to maintain progress and to increase the integrated sustainability attentions (Astier et al., 2012; Gibson, 2012). Parikhani et al. (2015) have found five barriers to application of "Good-Agricultural-Practices" technologies in livestock units of Meshkinshahr County as the infrastructural, informational-educational, institutional-support, economical, and personal, respectively. Baksh et al. (2015) have considered 100 small scale commercial vegetable farmers from 10 major-populated agricultural areas across Trinidad, and found an overall good knowledge, fairly positive attitudes of farmers but strong negative perceptions was observed towards the agricultural occupational health \& safety issues. By the use of non-renewable resources, most of the inorganic fertilizers as well as chemicals used in agricultures are manufactured such as fossil fuels contributing to pollution and environmental-degradation, and thus results in un-sustainable production in agriculture (Atoma and Atoma, 2015). Parker et al. (2016) have used mental models framework to help in developing an out-reach program for addressing produce-safety in Amish communities in Ohio. The findings of their study expanded the understandings of Amish-growers' perceptions as well as knowledge of on-farm produce-safety practices in the areas like the microbialrisks to fresh \& fresh-cut produces, contamination prevention practices, the economic feasibility perceptions of adopting these practices, preparedness for a contamination-event, and information needs with preferences. In a study of farm-workers in Ethiopia, it was found of not receiving any training on chemical-pesticides for $85 \%$ of the workers, and only $10 \%$ of workers were found of using personal protective equipments with a poor attitude as well as practice in chemical-pesticides handling (Negatu et al., 2016). The gender, safety-training as well as work-regulations were reported to affect the knowledge-levels of the participants regarding the safety issues (Aluko et al., 2016; Tetemke et al., 2014). Gaviglio et al. (2017) have considered the 'South-Milan Agricultural-Park' in Italy, and developed an assessment framework for farm-sustainability based on three aspects: (i) data-collection through interviews with farmers as well as institutions, (ii) elaborating data through aggregative structures, and (iii) scores-analysis. Zeeshan et al. (2017) have assessed the level of knowledge as well as practices of food safety handling among university students and explored the association between knowledge/practices and the academic as well as socio-demographic characteristics. The random and un-safe use of pesticides in agriculture creates major hazards to the environment as well 
as human health. Gesesew et al. (2017) have assessed the knowledge, attitudes as well as experiences of exposure to pesticides, and related health-problems among farmers using irrigation in Jimma-Zone (Southwest Ethiopia). Further, Jallow et al. (2017) have considered the Kuwaiti farmers about the safer uses of pesticides. Agricultural capabilities include feeding its population, serving as a revenue source to the nation, providing employments as well as employment opportunities, and serving as raw-materials source to agro-related business. At present these functions may not be met because of the rapid growth in population affecting the food production rate and thus reducing to sell overseas (Oluwaseyi, 2017). Apart from discomforts, the personal protective equipment brings in additional physiological burdens to the users by augmentation in heat stresses, heart rates and core temperatures considerably (Coca et al., 2017). Öztas et al. (2018) have evaluated the farmers' knowledge levels in the Çukurova region regarding the pesticides effects, toxic-symptoms, \& protective-equipment, and by assessing the attitudes and practices of the farmers about pesticides, an inadequate level of knowledge of farmers about safer use of pesticides was found. Scheinberg et al. (2018) have suggested for a customized food-safety training-program that would greatly benefit the farmers' market vendors for selling safer foods in Pennsylvania, by addressing the recognized issues in addition to the regulatory requirements. The inter-dependencies between different dimensions for farms-sustainability were assessed by Sulewski et al. (2018), which was carried out by considering 601 farms' participation in the "Polish-Farm Accountancy-Data Network". This was supported by supplementary information from interviews, and on a number of variables, including economical, social, environmental, and composite indices for sustainability-measures. Guma et al. (2018) have found a decrease in croplands with the increase in population, as energy, foods and spaces have been a prime requirement for the growing population. In a study with the consideration of 425 respondents from public-sector organizations in Pakistan, Irfan et al. (2018) have used a survey-based method and "partial least squares structural equation modelling (PLSSEM)" and found a positive relationship between social, environmental, as well as economic sustainability indices and the corporate-reputation. Inaccessibility of pertinent as well as quantifiable indicators depresses the specialists in sustainability-performance assessments. General as well as overall indicators for sustainability should be utilized for specific industrial-sectors (Hsu et al., 2017; Hegab et al., 2018).An integrated sustainability-assessment method has been demonstrated by Ahmad et al. (2019) with the use of the "Monte Carlo Simulation" and "fuzzy logic" approaches in a case study of a "Malaysian food-manufacturing company". It was found for the company to improve its sustainability-performance more effectively by decreasing the amount of polluted waste-water, air-emissions, etc., and through improvement in the workingconditions. Rostami et al. (2019) have proposed of educational sets consisting of contact with poisons as well as their applications, storages, pesticides carrying, effectiveness of different methods in individual protection facilities, and utilization of the behaviour for reduction of the poisons exposures to be developed and to be made available to the farmers in Kabudrahang County, Iran. Asgedom et al. (2019) have used structured questionnaires in two particleboard factories in Ethiopia, and found a higher proportion of positive-response of the permanent workers on knowledge and attitude towards chemical hazards than the temporary workers. However, very few temporary workers were provided with personal protective equipment as compared to the permanent workers. Mahajan and Patil (2019) have tried to identify strengths, weaknesses, opportunities, and threats for agro-based industrial sectors in India. Zelinka and Amadei (2019) have proposed a methodology by the use of system-dynamics to model the "time-dependent progress" of each one of the 17 "Sustainable Development Goals (SDGs)", as well as their mutual-interactions. Bahşi and Kendi (2019) have investigated the farmers' knowledge levels operating agricultural activities of Osmaniye and Konya regions in Turkey. It was observed of having no ideas about occupational health and safety of $45.9 \%$ farmers, while only $24.3 \%$ of having education about occupational health and safety. Moreover, statistical significant differences were found in age of farmers and learning status, occupational health and safety views of farmers, and their occupational health \& safety knowledge requirements in agriculture. It was suggested to establish more awareness on occupational health and safety in the agricultural sectors. Kizito and 
Semwanga (2020) have demonstrated the need for a shared-system wide-responsibility for road-safety at all levels by modeling the occurrences of road-accidents in Uganda by the use of "dynamic-synthesis methodology (DSM)". In this study, focus was given on road-accidents prevention by considering the linear as well as non-linear interactions of the variables during the pre-crash phases. Therefore, an attempt was made in this study to investigate the major barriers to the adoption of good safety practices in the agricultural sectors of Odisha in India for its sustainability.

Further, the "strengths, weaknesses, opportunities and threats (SWOT)" analysis has been widely preferred and used in agricultural evaluations. For instance, Humphrey (2005) has used SWOT analysis for evaluating the organic agriculture based on the current agricultural production set-ups as well as progress policies in Bhutan. Kumar and Nain (2013) have made a SWOT analysis of Indian agricultures. The strength was found to lie in having the largest cultivable-lands with food grains production evidences, while weakness was found to lie in having lower yields, not as much of value additions and food-processing and larger quantity of losses in post-harvest. On the basis of primary as well as secondary information from farmers that were obtained by the team members of "Krishi Vigyan Kendra", the SWOT analysis was carried out by considering the existing farming system in rural areas at Amreli district, Junagadh (Gujarat state in India). The identified strategies playing a vital role in farming system development and in growing of food security in those areas were: "growth of local market-opportunities and in storage-infrastructures", "plantation of crops with higher economic-values", "growth of governmental-supports", "preparation of strategic-plans for development in organic-farming", "taking into account of the quality of crops", "taking into consideration the farm sustainability-indexes", "use of sustainable water resources-management", and "developing extension-programs based on needs of farmers", respectively (Deshmukh et al., 2014). Similarly, Tashi and Wangchuk (2016) have used SWOT analysis to investigate the organic agriculture prospects in Bhutan based on the experts' point of views.

Moreover, a number of studies have used the "Multi-Criteria Decision-Making (MCDM)" methods that include several techniques for supporting decisions which involves conflicting criterion, disproportionate variables, and a number of possible alternatives or solutions (Doumpos and Zopounidis, 2014; Pohekar and Ramachandran, 2004; Shukla et al., 2019). In order to evaluate the barriers for developing landfill communities, the "interpretive structural modelling-ISM" methodology was used in a study (Chandramowli et al., 2011). Pradhan (2017) has proposed dynamic-heuristics pattern for risk-optimization on "Real Time Operating System (RTOS)" based on available technologies, businesses \& resources for anti-fragile technologies. However, the "COmplex PRoportional ASsessment (COPRAS)" method has been widely used when the optimal alternative need to be selected by decision-makers among a pool of alternatives in view of a set of evaluation criteria. In case of classical COPRAS method for the evaluation process, the weights of criterion along with the ratings of alternatives are precisely known and the crisp values are employed. Because of the in capabilities of the crisp data in modelling real-life decision problems under several conditions, it becomes difficult for the evaluators for precise ratings of alternatives as well as to assign exact weights to the evaluation criterion. Thus, the benefit of using a fuzzy-approach is to find out the relative importance of attributes by the use of fuzzy numbers rather than the numbers precisely. Parezanović et al. (2016) have demonstrated the "Fuzzy-COPRAS" approach in order to make decisions on mobility measures by evaluating twenty six measures. Bekar et al. (2016) have used the "COPRAS of alternatives with Grey relations (COPRAS-G)" and the "Fuzzy-COPRAS" method for evaluating the performance measures in "total productive maintenance (TPM)" strategy. Zarbakhshnia et al. (2018) have used fuzzy-COPRAS method for ranking and selecting the "sustainable third-party reverse logistics providers" in the existence of risk factors. Therefore, on the basis of the positive outcomes of the MCDM method, the "Fuzzy-COPRAS" method was used in the present analysis for ranking of the barriers in the execution of agricultural safety practices in India. 


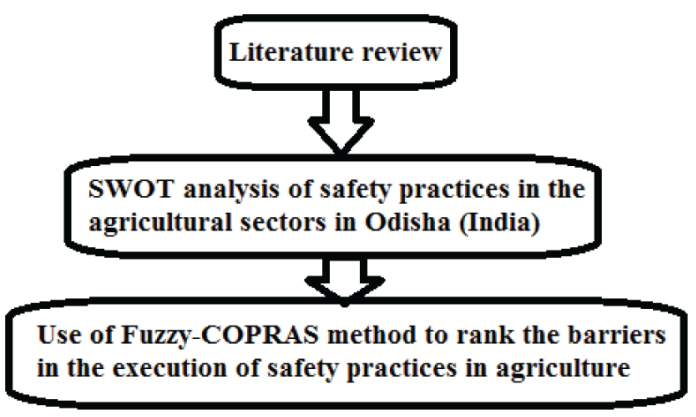

\section{RESEARCH METHODOLOGY}

\subsection{Review of Literature and Discussion With Experts and Farmers}

An in depth review of literature was done which was further followed by consultation and discussion with five experts in the agricultural fields and discussion with the farmers in the agricultural sectors of Odisha (India). The interaction and discussion with farmers was primarily focused on their knowledge levels, availabilities, and safety practices followed in carrying out the agricultural activities on a regular basis.

\subsection{Analysis of "Strengths, Weaknesses, Opportunities, and Threats (SWOT)"}

A SWOT analysis was employed in order to evaluate the strengths, weaknesses, opportunities, and the threats based on the current agriculture safety practices by the farmers for a sustainable agriculture.

\subsection{Analysis of Information and Data}

On the basis of the data and information obtained from the farmers as well as the experts, the major barriers in context with the sustainability indicators (social, environmental and economic) for the adoption of health and safety practices among farmers of Odisha were obtained. Then, the fuzzyCOPRAS method was used to rank these barriers in order of their preferences.

The steps followed in this analysis were as shown in Figure 1.

\subsubsection{Steps in "Fuzzy-COPRAS" Method}

In order to deal with the deficiency in the COPRAS method, the Fuzzy-COPRAS method was used in this analysis. The Fuzzy-COPRAS assigned the criteria weights, and the linguistic terms represented by fuzzy numbers were used for evaluating the ratings of alternatives. The steps involved in the Fuzzy-COPRAS method included the following:

Step I: Defining the linguistic terms.

Step II: Construction of the fuzzy decision matrix.

Step III: Determination of the weights of criteria.

Step IV: Determination of aggregate fuzzy-rating $\hat{x}_{i j}$ of alternative $\mathrm{A}_{\mathrm{i},} \mathrm{i}=1,2, \ldots, \mathrm{m}$ under criterion $\mathrm{C}_{\mathrm{j}, \mathrm{j}} \mathrm{j}=1,2, \ldots . \mathrm{n}$ :

$\mathrm{C}_{1} \mathrm{C}_{2} \ldots \mathrm{C}_{\mathrm{n}}$ 


$$
\begin{aligned}
& \hat{D}=\begin{array}{c}
A_{1} \\
A_{2} \\
\vdots \\
A_{M}
\end{array}\left[\begin{array}{cccc}
\tilde{x}_{11} & \tilde{x}_{12} & \cdots & \tilde{x}_{1 n} \\
\tilde{x}_{21} & \tilde{x}_{22} & \vdots & \tilde{x}_{2 n} \\
\vdots & \vdots & \ddots & \vdots \\
\tilde{x}_{m 1} & \tilde{x}_{m 2} & \vdots & \tilde{x}_{\mathrm{mn}}
\end{array}\right], \mathrm{i}=1,2, \ldots . \mathrm{m} ; \mathrm{j}=1,2, \ldots \mathrm{n} \\
& \tilde{x}_{i j}=\left(x_{i j 1}, x_{i j 2}, x_{i j 3}\right) \\
& \left.\left.x_{i j 1}=\min x_{i j k 1}\right\}, x_{i j 2}=\frac{1}{k} \sum_{k=1}^{k} x_{i j k 2}, x_{i j 1}=\min x_{i j k 3}\right\}
\end{aligned}
$$

where, $\hat{x}_{i j k}$ is the rating of alternative $\mathrm{A}_{\mathrm{i}}$ with respect to criterion $\mathrm{C}_{\mathrm{j}}$ evaluated by $\mathrm{k}^{\text {th }}$ expert (here $\mathrm{k}$ $=8), \tilde{x}_{i j \mathrm{k}}=\left(\tilde{x}_{i j \mathrm{k} 1}, \tilde{x}_{i j \mathrm{k} 2}, \tilde{x}_{i j \mathrm{k} 3}\right)$.

Step V: Defuzzifying the aggregated fuzzy decision matrix obtained and deriving their crisp values. In this analysis for transforming the fuzzy weights into the crisps weights applied the centre of area method for the calculation of the "best non-fuzzy performance (BPN)" value of the fuzzy weight of each dimensions. The BPN values of the fuzzy number $\tilde{x}_{i j}$ can be found using the following equation (3):

$$
\tilde{x}_{i j}=\tilde{x}_{i j} \tilde{x}_{i j}=\frac{\left[\left(U \tilde{x}_{i j}-L \tilde{x}_{i j}\right)+\left(M \tilde{x}_{i j}-L \tilde{x}_{i j}\right)\right]}{3}+\mathrm{L} \tilde{x}_{i j}
$$

Step VI: Normalizing the decision matrix $\left(\mathrm{f}_{\mathrm{ij}}\right)$. The normalization of the decision making is calculated by dividing each entry by the largest entry in each column to eliminate anomalies with different measurement units, so that all the criteria become dimensionless.

Step VII: Calculating the weighted normalized decision matrix $\left(\hat{x}_{i j}\right)$ The fuzzy-weighted normalized values are calculated by multiplying the weight of evaluation indicator $\left(\mathrm{w}_{\mathrm{j}}\right)$ with normalized decision matrices:

$$
\hat{x}_{i j}=\mathrm{f}_{\mathrm{ij}} \cdot \mathrm{w}_{\mathrm{j}}
$$

Step VIII: Sums of attributed values $\left(\mathrm{P}_{\mathrm{i}}\right)$ with larger values more preferably (optimization direction is maximization) calculated for each alternative (line of the decision-making matrix):

$$
\mathrm{P}_{\mathrm{i}}=\sum_{j=1}^{k} \hat{x}_{i j}
$$

Step IX: Sums of attributed values $\left(\mathrm{R}_{\mathrm{i}}\right)$ with smaller values more preferably (optimization direction is minimization) calculated for each alternative (line of the decision-making matrix):

$$
\mathrm{R}_{\mathrm{i}}=\sum_{j=k+1}^{m} \hat{x}_{i j}
$$

where, (m-k) is number of attributes which must be minimized. 
Step X: Determining the minimal value of $\left(\mathrm{R}_{\mathrm{i}}\right)$ :

$\mathrm{R}_{\min }=\max _{i} \mathrm{R}_{\mathrm{i}} ; \mathrm{i}=1, \ldots, \mathrm{n}$

Step XI: Calculating the relative weight of each alternative $\left(Q_{i}\right)$ :

$$
\mathrm{Q}_{\mathrm{i}}=\mathrm{P}_{\mathrm{i}}+\frac{R \min \sum_{i=1}^{n} R i}{R i \sum_{i=1}^{n} \frac{R m i n}{R i}}
$$

Formula (8) can to be written as:

$$
\mathrm{Q}_{\mathrm{i}}=\mathrm{P}_{\mathrm{i}}+\frac{\sum_{i=1}^{n} R i}{R i \sum_{i=1}^{n} \frac{1}{R i}}
$$

Step XII: Determining the optimality criterion k:

$$
\mathrm{K}=\max _{i} \mathrm{Q}_{\mathrm{i} ;} \mathrm{i}=\overline{1, n}
$$

Step XIII: Assigning the priority of the alternatives. The greater the weight (relative weight of alternative) $\mathrm{Q}_{\mathrm{i}}$, the higher is the priority (rank) of the alternatives. The satisfaction degree is high in case of $\mathrm{Q}_{\max }$.

Then, the utility degree of each alternative was calculated as:

$\mathrm{N}_{\mathrm{i}}=\frac{Q i}{Q \max } \times 100$

where, $\mathrm{Q}_{\mathrm{i}}$ and $Q \max$ are the weights obtained from equation (8).

\section{RESULTS AND DISCUSSION}

The SWOT analysis of safety practices among farmers in Odisha in context with its sustainability in agriculture in view of the sustainability criteria such as social, environmental and economic aspects was as illustrated in Table 1.

The major barriers as alternatives in context with the sustainability indicators as criterion for the adoption of health and safety practices among farmers of Odisha in India were summarized in Table 2. The identified four barriers concerned to the "Social" indicators were: "Lack of assistance from government, non-government and industry bodies with regard to health and safety practices", "Lack 
Table 1. SWOT analysis of safety practices among farmers in Odisha and its sustainability in agriculture

\begin{tabular}{|c|c|c|c|}
\hline \multirow[t]{3}{*}{ Strength } & $\begin{array}{l}\text { Leading to sustainable } \\
\text { agriculture with respect to } \\
\text { health and environment. }\end{array}$ & \multirow[t]{3}{*}{ Weakness } & \multirow[t]{2}{*}{$\begin{array}{l}\text { Lack of awareness among } \\
\text { farmers. }\end{array}$} \\
\hline & Reduced risk to farmers. & & \\
\hline & $\begin{array}{l}\text { Reduced risk of exposing } \\
\text { to harmful chemicals and } \\
\text { pesticides. }\end{array}$ & & $\begin{array}{l}\text { Lack of adoptability } \\
\text { perception among farmers. }\end{array}$ \\
\hline \multirow[t]{3}{*}{ Opportunity } & $\begin{array}{l}\text { Promoting a healthier } \\
\text { lifestyle. }\end{array}$ & \multirow[t]{3}{*}{ Threats } & \multirow[t]{2}{*}{$\begin{array}{l}\text { Unsure about the outcome } \\
\text { of safety practices. }\end{array}$} \\
\hline & $\begin{array}{l}\text { A huge export market at } \\
\text { regional level. }\end{array}$ & & \\
\hline & $\begin{array}{l}\text { A huge export market at } \\
\text { international level }\end{array}$ & & $\begin{array}{l}\text { Lack of availability in local } \\
\text { markets. }\end{array}$ \\
\hline
\end{tabular}

Table 2. Major barriers in context with the sustainability for the adoption of health and safety practices

\begin{tabular}{|c|c|}
\hline Sustainability Indicators & Barriers \\
\hline \multirow{4}{*}{ Social $\left(\mathrm{C}_{1}\right)$} & $\begin{array}{l}\text { Lack of assistance from government, non-government and } \\
\text { industry bodies with regard to health and safety practices }\left(\mathrm{B}_{1}\right)\end{array}$ \\
\hline & $\begin{array}{l}\text { Lack of proper training and programs about safety } \\
\text { practices }\left(\mathrm{B}_{2}\right)\end{array}$ \\
\hline & Discomfort in use of safety devices and practices $\left(\mathrm{B}_{3}\right)$ \\
\hline & More time in the implementation of safety practices $\left(B_{4}\right)$ \\
\hline \multirow{3}{*}{ Environmental $\left(\mathrm{C}_{2}\right)$} & Lack of access to information about safety practices $\left(\mathrm{B}_{5}\right)$ \\
\hline & Non-availability of protective appliances for a regular use $\left(B_{6}\right)$ \\
\hline & $\begin{array}{l}\text { Hassle to the source and in the implementation of safety } \\
\text { practices }\left(B_{7}\right)\end{array}$ \\
\hline \multirow{3}{*}{ Economic $\left(\mathrm{C}_{3}\right)$} & $\begin{array}{l}\text { More cost to implement changes for improved safety } \\
\text { practices }\left(B_{8}\right)\end{array}$ \\
\hline & Inadequate finance for health surveillance programs $\left(B_{9}\right)$ \\
\hline & $\begin{array}{l}\text { Lack of initiatives for subsidized appliances through } \\
\text { government }\left(B_{10}\right)\end{array}$ \\
\hline
\end{tabular}

of proper training and programs about safety practices", "Discomfort in use of safety devices and practices", and "More time in the implementation of safety practices". The three barriers concerned to the "Environmental" indicators were "Lack of access to information about safety practices", "Non-availability of protective appliances for a regular use, and "Hassle to the source and in the implementation of safety practices". Similarly, the three barrier obtained as the "Economic" indicator for sustainability were: More cost to implement changes for improved safety practices", "Inadequate finance for health surveillance programs", and "Lack of initiatives for subsidized appliances through government", respectively.

\subsection{Output of "Fuzzy-COPRAS" Method}

The criteria along with its types and corresponding weights were as illustrated in Table 3. 
Table 3. Different criteria weights

\begin{tabular}{|c|c|c|}
\hline Name of Criteria & Type of Criteria & Weights $\left(\mathbf{W}_{\mathrm{R}}\right)$ \\
\hline \multirow{3}{*}{ Social $\left(\mathrm{C}_{\mathrm{R} 1}\right)$} & \multirow{3}{*}{ Minimization } & 0.77 \\
\hline & & 0.83 \\
\hline & & 0.98 \\
\hline \multirow{3}{*}{ Environmental $\left(\mathrm{C}_{\mathrm{R} 2}\right)$} & \multirow{3}{*}{ Minimization } & 0.65 \\
\hline & & 0.78 \\
\hline & & 0.88 \\
\hline \multirow{3}{*}{ Economic $\left(\mathrm{C}_{\mathrm{R} 3}\right)$} & \multirow{3}{*}{ Minimization } & 0.77 \\
\hline & & 0.95 \\
\hline & & 0.1 \\
\hline
\end{tabular}

The initial integrated-matrix comprising of the weights of all the criterion and corresponding fuzzy numbers of each alternatives with respect to the criteria were as shown in Table 4. Subsequently, the sum of squares and square-root (SQRT) values were obtained as illustrated in Table 5.

The normalized-matrix and the weighted normalized-matrix were as shown in Table 6 and Table 7 , respectively.

Table 4. Initial integrated-matrix

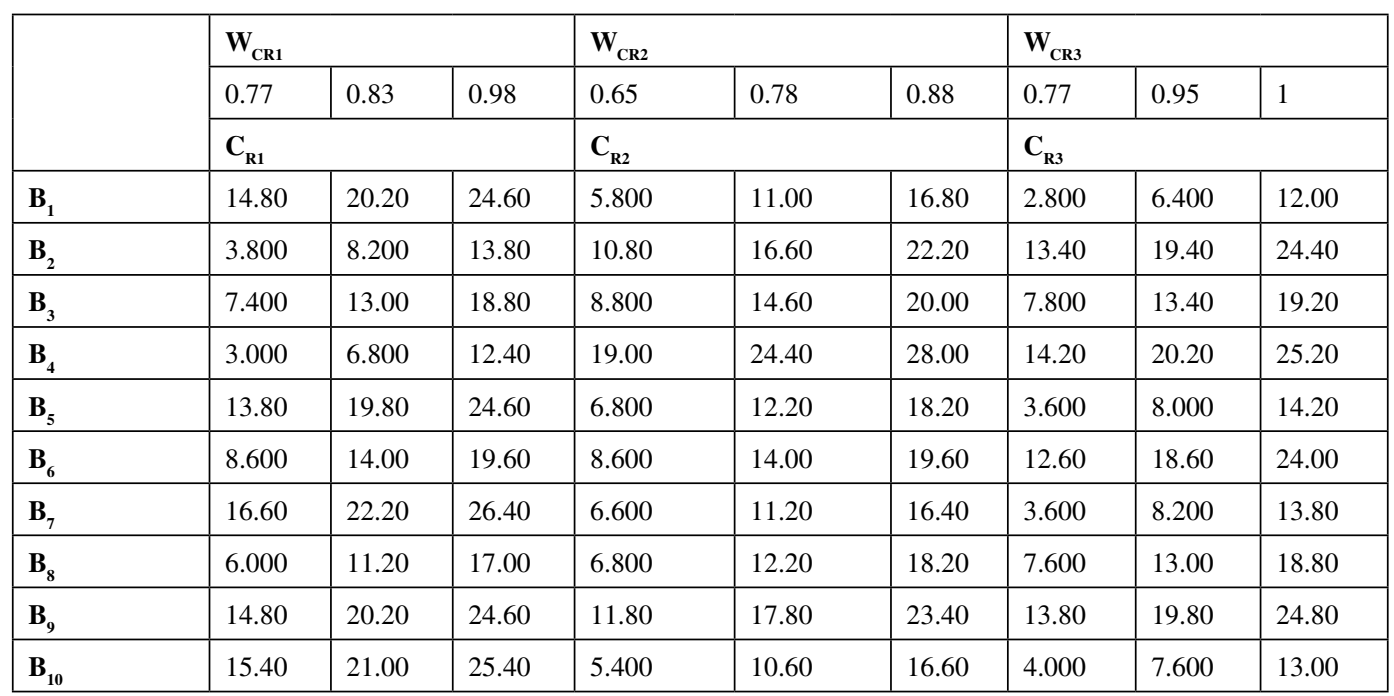

Table 5. Sum of squares and "SQRT" values

\begin{tabular}{|l|l|l|l|l|l|l|l|l|l|}
\hline Sum of Squares & 1329.4 & 2745.8 & 4528.4 & 967.12 & 2253.4 & 4097.8 & 898.76 & 2100.9 & 3848.6 \\
\hline SQRT & 92.756 & 85.547 & 82.754 \\
\hline
\end{tabular}


Table 6. Normalized-matrix

\begin{tabular}{|c|c|c|c|c|c|c|c|c|c|}
\hline & \multicolumn{3}{|l|}{$\mathbf{W}_{\mathrm{CR} 1}$} & \multicolumn{3}{|l|}{$\mathbf{W}_{\mathrm{CR} 2}$} & \multicolumn{3}{|l|}{$\mathbf{W}_{\mathrm{CR} 3}$} \\
\hline & 0.77 & 0.83 & 0.98 & 0.65 & 0.78 & 0.88 & 0.77 & 0.95 & 1 \\
\hline & \multicolumn{3}{|l|}{$\mathrm{C}_{\mathrm{R} 1}$} & \multicolumn{3}{|l|}{$\mathrm{C}_{\mathrm{R} 2}$} & \multicolumn{3}{|l|}{$\mathrm{C}_{\mathrm{R} 3}$} \\
\hline $\mathbf{B}_{1}$ & 0.1596 & 0.2178 & 0.2652 & 0.0678 & 0.1286 & 0.1964 & 0.0338 & 0.0773 & 0.1450 \\
\hline $\mathbf{B}_{2}$ & 0.0410 & 0.0884 & 0.1488 & 0.1262 & 0.1940 & 0.2595 & 0.1619 & 0.2344 & 0.2948 \\
\hline $\mathbf{B}_{3}$ & 0.0798 & 0.1402 & 0.2027 & 0.1029 & 0.1707 & 0.2338 & 0.0943 & 0.1619 & 0.2320 \\
\hline $\mathbf{B}_{4}$ & 0.0323 & 0.0733 & 0.1337 & 0.2221 & 0.2852 & 0.3273 & 0.1716 & 0.2441 & 0.3045 \\
\hline $\mathbf{B}_{5}$ & 0.1488 & 0.2135 & 0.2652 & 0.0795 & 0.1426 & 0.2127 & 0.0435 & 0.0967 & 0.1716 \\
\hline B $_{6}$ & 0.0927 & 0.1509 & 0.2113 & 0.1005 & 0.1637 & 0.2291 & 0.1523 & 0.2248 & 0.2900 \\
\hline $\mathbf{B}_{7}$ & 0.1790 & 0.2393 & 0.2846 & 0.0772 & 0.1309 & 0.1917 & 0.0435 & 0.0991 & 0.1668 \\
\hline $\mathbf{B}_{8}$ & 0.0647 & 0.1207 & 0.1833 & 0.0795 & 0.1426 & 0.2127 & 0.0918 & 0.1571 & 0.2272 \\
\hline $\mathrm{B}_{9}$ & 0.1596 & 0.2178 & 0.2652 & 0.1379 & 0.2081 & 0.2735 & 0.1668 & 0.2393 & 0.2997 \\
\hline $\mathrm{B}_{10}$ & 0.1660 & 0.2264 & 0.2738 & 0.0631 & 0.1239 & 0.1940 & 0.0483 & 0.0918 & 0.1571 \\
\hline
\end{tabular}

Table 7. Weighted normalized-matrix

\begin{tabular}{|l|l|l|l|l|l|l|l|l|l|}
\hline & \multicolumn{9}{|l}{$\mathbf{C}_{\mathbf{R} 1}$} \\
\hline & 0.1229 & 0.1808 & 0.2599 & 0.0441 & 0.1003 & 0.1728 & 0.0261 & 0.0735 & 0.1450 \\
\hline $\mathbf{B}_{\mathbf{1}}$ & 0.0315 & 0.0734 & 0.1458 & 0.0821 & 0.1514 & 0.2284 & 0.1247 & 0.2227 & 0.2948 \\
\hline $\mathbf{B}_{\mathbf{2}}$ & 0.0614 & 0.1163 & 0.1986 & 0.0669 & 0.1331 & 0.2057 & 0.0726 & 0.1538 & 0.2320 \\
\hline $\mathbf{B}_{\mathbf{3}}$ & 0.0249 & 0.0608 & 0.1310 & 0.1444 & 0.2225 & 0.2880 & 0.1321 & 0.2319 & 0.3045 \\
\hline $\mathbf{B}_{\mathbf{4}}$ & 0.1146 & 0.1772 & 0.2599 & 0.0517 & 0.1112 & 0.1872 & 0.0335 & 0.0918 & 0.1716 \\
\hline $\mathbf{B}_{\mathbf{5}}$ & 0.0714 & 0.1253 & 0.2071 & 0.0653 & 0.1276 & 0.2016 & 0.1172 & 0.2135 & 0.2900 \\
\hline $\mathbf{B}_{\mathbf{6}}$ & 0.1378 & 0.1987 & 0.2789 & 0.0501 & 0.1021 & 0.1687 & 0.0335 & 0.0941 & 0.1668 \\
\hline $\mathbf{B}_{\mathbf{7}}$ & 0.0498 & 0.1002 & 0.1796 & 0.0517 & 0.1112 & 0.1872 & 0.0707 & 0.1492 & 0.2272 \\
\hline $\mathbf{B}_{\mathbf{8}}$ & 0.1229 & 0.1808 & 0.2599 & 0.0897 & 0.1623 & 0.2407 & 0.1284 & 0.2273 & 0.2997 \\
\hline $\mathbf{B}_{\mathbf{9}}$ & 0.1278 & 0.1879 & 0.2684 & 0.0410 & 0.0966 & 0.1708 & 0.0372 & 0.0872 & 0.1571 \\
\hline $\mathbf{B}_{\mathbf{1 0}}$ & & & & & & & & \\
\hline
\end{tabular}

The ranking of alternatives were based on the higher values of $\mathrm{N}_{\mathrm{i}}$ as summarized in Table 8 , and it was observed that the most significant barriers in context with the sustainability for the adoption of health and safety practices in Odisha such as "More cost to implement changes for improved safety practices $\left(\mathrm{B}_{8}\right)$ " ranked first followed by "Lack of assistance from government, non-government and industry bodies with regard to health and safety practices $\left(\mathrm{B}_{1}\right)$ ", "Lack of access to information about safety practices $\left(\mathrm{B}_{5}\right)$ ", "Discomfort in use of safety devices and practices $\left(\mathrm{B}_{3}\right)$ ", "Lack of initiatives for subsidized appliances through government $\left(\mathrm{B}_{10}\right)$ ", "Hassle to the source and in the implementation of safety practices $\left(\mathrm{B}_{7}\right)$ ", "Lack of proper training and programs about safety practices $\left(\mathrm{B}_{2}\right)$ ", "Non-availability of protective appliances for a regular use $\left(\mathrm{B}_{6}\right)$ ", "More time in the implementation of safety practices $\left(\mathrm{B}_{4}\right)$ ", and "Inadequate finance for health surveillance programs $\left(\mathrm{B}_{9}\right)$ ", respectively. 


\begin{tabular}{|l|l|l|l|l|l|l|l|l|l|l|l|l|}
\hline \multirow{2}{*}{ Alternatives } & \multicolumn{3}{|c|}{$\mathbf{P}_{\mathbf{j}}$} & \multicolumn{3}{|c|}{$\mathbf{R}_{\mathbf{j}}$} & \multicolumn{3}{|c|}{$\mathbf{Q}_{\mathbf{j}}$} & $\begin{array}{c}\text { Non- } \\
\text { Fuzzy } \\
\mathbf{Q}_{\mathbf{j}}\end{array}$ & $\mathbf{N}_{\mathbf{j}}$ & Ranking \\
\hline $\mathbf{B}_{\mathbf{1}}$ & 0 & 0 & 0 & 0.193 & 0.354 & 0.577 & 0.030 & 0.501 & 6.549 & 2.360 & 90.06 & $\mathbf{2}$ \\
\hline $\mathbf{B}_{\mathbf{2}}$ & 0 & 0 & 0 & 0.238 & 0.447 & 0.669 & 0.026 & 0.397 & 5.304 & 1.909 & 72.85 & $\mathbf{7}$ \\
\hline $\mathbf{B}_{\mathbf{3}}$ & 0 & 0 & 0 & 0.200 & 0.403 & 0.636 & 0.027 & 0.441 & 6.292 & 2.253 & 85.98 & $\mathbf{4}$ \\
\hline $\mathbf{B}_{\mathbf{4}}$ & 0 & 0 & 0 & 0.301 & 0.515 & 0.723 & 0.024 & 0.345 & 4.194 & 1.521 & 58.03 & $\mathbf{9}$ \\
\hline $\mathbf{B}_{\mathbf{5}}$ & 0 & 0 & 0 & 0.199 & 0.380 & 0.618 & 0.028 & 0.467 & 6.328 & 2.275 & 86.79 & $\mathbf{3}$ \\
\hline $\mathbf{B}_{\mathbf{6}}$ & 0 & 0 & 0 & 0.254 & 0.466 & 0.698 & 0.025 & 0.381 & 4.977 & 1.794 & 68.46 & $\mathbf{8}$ \\
\hline $\mathbf{B}_{\mathbf{7}}$ & 0 & 0 & 0 & 0.221 & 0.394 & 0.614 & 0.028 & 0.450 & 5.708 & 2.062 & 78.68 & $\mathbf{6}$ \\
\hline $\mathbf{B}_{\mathbf{8}}$ & 0 & 0 & 0 & 0.172 & 0.360 & 0.594 & 0.02 & 0.493 & 7.340 & 2.621 & 100 & $\mathbf{1}$ \\
\hline $\mathbf{B}_{\mathbf{9}}$ & 0 & 0 & 0 & 0.340 & 0.570 & 0.800 & 0.022 & 0.312 & 3.707 & 1.347 & 51.39 & $\mathbf{1 0}$ \\
\hline $\mathbf{B}_{\mathbf{1 0}}$ & 0 & 0 & 0 & 0.206 & 0.371 & 0.596 & 0.029 & 0.478 & 6.133 & 2.213 & 84.45 & $\mathbf{5}$ \\
\hline
\end{tabular}

\section{CONCLUSION}

Agriculture is the primary source of food and livelihood in most of the developing countries. Thus, there is a higher requirement of sustainable agricultural systems fulfilling the sustainability criteria such as economic, social as well as environmental aspects of safe and healthy agriculture in terms of accessibility or availability, utilizations and stability in the farming sectors. This study revealed that the most significant barriers that require appropriate attentions of the competent-authorities in context with the sustainability for the adoption of health and safety practices in the agricultural sectors of Odisha as: "More cost to implement changes for improved safety practices" ranking at first level, which was followed by subsequent descending ranking of "Lack of assistance from government, non-government and industry bodies with regard to health and safety practices", "Lack of access to information about safety practices", "Discomfort in use of safety devices and practices", "Lack of initiatives for subsidized appliances through government", "Hassle to the source and in the implementation of safety practices", "Lack of proper training and programs about safety practices", "Non-availability of protective appliances for a regular use", "More time in the implementation of safety practices", and "Inadequate finance for health surveillance programs", respectively.

The findings of this study will help in formulating appropriate policies in the agricultural sectors for the benefits as well as protection of farmers in view of the ill-hazards in agriculture. Moreover, a clear information and explanation about new technology and safety practices more usable to farmers reduces negative attitude towards the effective and efficient adoption. There is a higher requirement in the role of agricultural extension agents that can affect farmers' perceptions as well as behaviors to adopt the agricultural health and safety practices in order to achieve sustainability in agriculture throughout the world.

\section{ACKNOWLEDGMENT}

We, the authors, express our sincere thanks to all the participants in this research work. Moreover, we are thankful to Dr. Suchismita Satapathy (Associate professor, SME, KIIT Deemed to be University) in providing adequate guidance and support to make this work successful. 


\section{REFERENCES}

Ahmad, S., Wong, K. Y., \& Zaman, B. (2019). A Comprehensive and Integrated Stochastic-Fuzzy Method for Sustainability Assessment in the Malaysian Food Manufacturing Industry. Sustainability, 11(4), 948. doi:10.3390/ su11040948

Aluko, O. O., Adebayo, A. E., Adebisi, T. F., Ewegbemi, M. K., Abidoye, A. T., \& Popoola, B. F. (2016). Knowledge, attitudes and perceptions of occupational hazards and safety practices in Nigerian healthcare workers. BMC Research Notes, 9(1), 71. doi:10.1186/s13104-016-1880-2 PMID:26852406

Asgedom, A. A., Bråtveit, M., \& Moen, B. E. (2019). Knowledge, attitude and practice related to chemical hazards and personal protective equipment among particleboard workers in Ethiopia: A cross-sectional study. BMC Public Health, 19(1), 440. doi:10.1186/s12889-019-6807-0 PMID:31029126

Astier, M., García-Barrios, L., Galván-Miyoshi, Y., González-Esquivel, C. E., \& Masera, O. R. (2012). Assessing the Sustainability of Small Farmer Natural Resource Management Systems: A Critical Analysis of the MESMIS Program. Ecology and Society, 17(3), 25. doi:10.5751/ES-04910-170325

Atoma, C. N., \& Atoma, J. O. (2015). Analysis of organic farming practices amongst crop farmers in Delta State, Nigeria. Journal of Information and Knowledge Management, 6(3), 213-220.

Bahşi, N., \& Kendi, O. (2019). Farmers' approaches on occupational health and safety: The case of city of Osmaniye and Konya, Turkey. Ciência Rural, Santa Maria, 49(04), e20181019. doi:10.1590/0103-8478cr20181019

Baksh, K., Ganpat, W., \& Narine, L. (2015). Farmers'knowledge, attitudes and perceptions of occupational health and safety hazards in Trinidad, West Indies and implications for the Agriculture sector. Journal of Agricultural Extension and Rural Development, 7(7), 221-228. doi:10.5897/JAERD2015.0672

Battisti, D. S., \& Naylor, R. L. (2009). Historical warnings of future food insecurity with unprecedented seasonal heat. Science, 323(5911), 240-244. doi:10.1126/science.1164363 PMID:19131626

Bekar, E. T., Cakmakci, M., \& Kahraman, C. (2016). Fuzzy COPRAS method for performance measurement in total productive maintenance: A comparative analysis. Journal of Business Economics and Management, 17(5), 663-684. doi:10.3846/16111699.2016.1202314

Bell, S., \& Morse, S. (2008). Sustainability indicators: measuring the immeasurable? Earthscan.

Caporali, F., \& Onnis, A. (1992). Validity of rotation as an effective agroecological principle for a sustainable agriculture. Agriculture, Ecosystems \& Environment, 41(2), 101-113. doi:10.1016/0167-8809(92)90104-J

Chandramowli, S., Transue, M., \& Felder, F. A. (2011). Analysis of barriers to development in landfill communities using interpretive structural modeling. Habitat International, 35(2), 246-253. doi:10.1016/j. habitatint.2010.09.005

Coca, A., Quinn, T., Kim, J. H., Wu, T., Powell, J., Roberge, R., \& Shaffer, R. (2017). Physiological Evaluation of Personal Protective Ensembles Recommended for Use in West Africa. Disaster Medicine and Public Health Preparedness, 17(5), 580-586. Advance online publication. doi:10.1017/dmp.2017.13 PMID:28303774

Conway, G. R., \& Barbier, E. B. (2013). After the green revolution: sustainable agriculture for development. Routledge. doi: $10.4324 / 9781315066820$

Conway, G. R., \& Pretty, J. N. (2013). Unwelcome harvest: agriculture and pollution. Routledge. doi:10.4324/9781315066844

Daly, H. E. (1990). Towards Some Operational Principals of Sustainable Development. Ecological Economics, 2(1), 1-6. doi:10.1016/0921-8009(90)90010-R

Deshmukh, G., Ahmad, S., Patil, A., Lende, S., \& Bariya, M. (2014). SWOT Analysis of Farming Situation of Major Crops and Growth Drivers. Journal of Agroecology and Natural Resource Management, 1(2), 95-97.

DFID. (2004). Agricultural sustainability: Working / Supporting Paper England. Retrieved on October 142019 from http://dfidagricultureconsultationnriorg/summaries/wp12pdf

DFID. (2003). Sustainable agriculture Keysheet. Retrieved on October 142019 from http://wwwodiorguk/sites/ odiorguk/files/odiassets/publications-opinion-files/3143pdf 
Diaz, R. J., \& Rosenberg, R. (2008). Spreading dead zones and consequences for marine ecosystems. Science, 321(5891), 926-929. doi:10.1126/science.1156401 PMID:18703733

Doumpos, M., \& Zopounidis, C. (2014). An overview of multiple criteria decision aid. Multicriteria analysis in finance. Springer.

Fan, S., Ringler, C., Nkonya, E., \& Stein, A. J. (2012). Ensuring food and nutrition security in a green economy. International Food Policy Research Institute. Retrieved on October 022019 from http://wwwifpriorg/sites/ default/files/publications/bp21pdf

FAO. (2013). Sustainability path way. Retrieved on October 122019 from http://wwwfaoorg/nr/sustainability/en/

Francis, C., Lieblein, G., Gliessman, S., Breland, T. A., Creamer, N., Harwood, R., \& Poincelot, R. (2003). Agroecology: The ecology of food systems. Journal of Sustainable Agriculture, 22(3), 99-118. doi:10.1300/ J064v22n03_10

Gates, D. M., \& Jones, M. S. (2007). A Pilot Study to Prevent Hearing Loss in Farmers. Public Health Nursing (Boston, Mass.), 24(6), 547-553. doi:10.1111/j.1525-1446.2007.00667.x PMID:17973732

Gaviglio, A., Bertocchi, M., \& Demartini, E. (2017). A Tool for the Sustainability Assessment of Farms: Selection, Adaptation and Use of Indicators for an Italian Case Study. Resources, 6(4), 60. doi:10.3390/resources6040060

Geer, L. A., Curbow, B. A., Anna, D. H., Lees, P. S. J., \& Buckley, T. J. (2006). Development of a questionnaire to assess worker knowledge, attitudes and perceptions underlying dermal exposure. Scandinavian Journal of Work, Environment \& Health, 32(3), 209-218. doi:10.5271/sjweh.1001 PMID:16804624

Gesesew, H. A., Woldemichael, K., Massa, D., \& Mwanri, L. (2016). Farmers Knowledge, Attitudes, Practices and Health Problems Associated with Pesticide Use in Rural Irrigation Villages, Southwest Ethiopia. PLoS One, 11(9), e0162527. doi:10.1371/journal.pone.0162527 PMID:27622668

Gibson, R. B. (2012). Why sustainability assessment. In A. J. Bond, A. Morrison-Saunders, \& R. Howitt (Eds.), Sustainability assessment: pluralism practice and progress. Routledge.

GIZ. (2012). What is sustainable agriculture German Federal Ministry for Economic Development and Cooperation (BMZ) Division. Rural Development and Global Food Security. Retrieved on October 122019 from http://wwwgizde/Themen/en/dokumente/giz2012-en-sustainable-agriculture.pdf

Godfray, H. C. J., Beddington, J. R., Crute, I. R., Haddad, L., Lawrence, D., Muir, J. F., \& Toulmin, C. (2010). Food security: The challenge of feeding 9 billion people. Science, 327(5967), 812-818. doi:10.1126/ science.1185383 PMID:20110467

Guma, I. P., Rwashana, A. S., \& Oyo, B. (2018). Food Security Indicators for Subsistence Farmers Sustainability: A System Dynamics Approach. International Journal of System Dynamics Applications, 7(1), 45-64. doi:10.4018/ IJSDA.2018010103

Gurr, G. M., Wratten, S. D., \& Luna, J. M. (2003). Multi-function agricultural biodiversity: Pest management and other benefits. Basic and Applied Ecology, 4(2), 107-116. doi:10.1078/1439-1791-00122

Hagel, L., Pahwa, P., Dosman, J. A., \& Pickett, W. (2013). Economic worry and the presence of safety hazards on farms. Accident; Analysis and Prevention, 53, 156-160. doi:10.1016/j.aap.2013.01.011 PMID:23434843

Hegab, H., Darras, B., \& Kishawy, H. (2018). Towards sustainability assessment of machining processes. Journal of Cleaner Production, 170, 694-703. doi:10.1016/j.jclepro.2017.09.197

Hsu, C. H., Chang, A. Y., \& Luo, W. (2017). Identifying key performance factors for sustainability development of SMEs-integrating QFD and fuzzy MADM methods. Journal of Cleaner Production, 161, 629-645. doi:10.1016/j. jclepro.2017.05.063

Humphrey, A. (2005). SWOT analysis for management consulting. SRI Alumni Newsletter, 1, 7-8.

IFOAM. (2007). Organic Agriculture-Role in Countering Climate Change. IFOAM. Available from: www. ifoam.org/en/benefits-organicagriculture 
Irfan, M., Hassan, M., \& Hassan, N. (2018). Unravelling the Fuzzy Effect of Economic, Social and Environmental Sustainability on the Corporate Reputation of Public-Sector Organizations: A Case Study of Pakistan. Sustainability, 10(3), 769. doi:10.3390/su10030769

Jackson-Smith, D. (2010). Toward Sustainable Agricultural Systems in the 21st Century. National Academies Press.

Jallow, M. F. A., Awadh, D. G., Albaho, M. S., Devi, V. Y., \& Thomas, B. M. (2017). Pesticide Knowledge and Safety Practices among Farm Workers in Kuwait: Results of a Survey. International Journal of Environmental Research and Public Health, 14(4), 340. doi:10.3390/ijerph14040340 PMID:28338612

Kates, R. W., Parris, T. M., \& Leiserowitz, A. A. (2005). What is sustainable development? Goals, indicators, values and practice. Environment (Washington DC), 47(3), 8-21.

Kaustell, K. O., Mattila, T. E. A., \& Rautiainen, R. H. (2011). Barriers and Enabling Factors for Safety Improvements on Farms in Finland. Journal of Agricultural Safety and Health, 17(4), 327-342. doi:10.13031/2013.39805 PMID:22164462

Kizito, A., \& Semwanga, A. R. (2020). Modeling the Complexity of Road Accidents Prevention: A System Dynamics Approach. International Journal of System Dynamics Applications, 9(2), 24-41. doi:10.4018/ IJSDA.2020040102

Kumar, P., \& Nain, M. S. (2013). Agriculture in India: A SWOT analysis. Indian Journal of Applied Research, 3(7), 4-6. doi:10.15373/2249555X/JULY2013/2

Lal, R. (1991). Tillage and agricultural sustainability. Soil \& Tillage Research, 20(2), 133-146. doi:10.1016/01671987(91)90036-W

MacFarlane, E., Chapman, A., Benke, G., Meaklim, J., Sim, M., \& McNeil, J. (2008). Training and other predictors of personal protective equipment use in Australian grain farmers using pesticides. BMJ Publishing Group, 65(2). 10.1136/oem.2007.034843

Mahajan, S. S., \& Patil, P. J. (2019). SWOT Analysis of Agro-Based Industry in India. EC Agriculture, 5(2), $102-105$.

McCullagh, M. P., \& Robertson, C. P. (2009). Too Late Smart: Farmers' Adoption of Self-Protective Behaviors in Response to Exposure to Hazardous Noise. AAOHN Journal, 57(3), 99-105. doi:10.1177/216507990905700304 PMID:19338259

Negatu, B., Kromhout, H., Mekonnen, Y., \& Vermeulen, R. (2016). Use of chemical pesticides in Ethiopia: A cross-sectional comparative study on knowledge, attitude and practice of farmers and farm Workers in Three Farming Systems. The Annals of Occupational Hygiene, 60(5), 551-566. doi:10.1093/annhyg/mew004 PMID:26847604

Okello, T. R., Kansime, K., Odora, J., Apio, J. A., \& Pecorella, I.Mary's Hospital Lacor in Northern Uganda. (2017). Barriers and Factors Affecting Personal Protective Equipment Usage in St. Mary's Hospital Lacor in Northern Uganda. East and Central African Journal of Surgery, 22(1), 59-65. doi:10.4314/ecajs.v22i1.8

Oluwaseyi, A. B. (2017). The prospects of agriculture in Nigeria: How our fathers lost their way-A review. Asian Journal of Economics. Business and Accounting, 4(2), 1-30.

Oyo, B., \& Kalema, B. M. (2016). A System Dynamics Model for Subsistence Farmers' Food Security Resilience in Sub-Saharan Africa. International Journal of System Dynamics Applications, 5(1), 17-30. doi:10.4018/ IJSDA.2016010102

Öztas, D., Kurt, B., Koç, A., Akbaba, M., \& Ilter, H. (2018). Knowledge Level, Attitude, and Behaviors of Farmers inÇukurova Region regarding the Use of Pesticides. Bio Med Research International. <ALIGNMENT. qj $></$ ALIGNMENT $>10.1155 / 2018 / 6146509$

Parezanović, T., Bojković, N., Petrović, M., \& Tarle, S. P. (2016). Evaluation of Sustainable Mobility Measures Using Fuzzy COPRAS Method. Management, 78, 53-62.

Parikhani, M. P., Borkhani, F. R., Fami, H. S., Motiee, N., \& Hosseinpoor, A. (2015). Major Barriers to Application of Good AgriculturalPractices (GAPs) Technologies in Sustainability of Livestock Units. International Journal of Agricultural Management and Development, 5(3), 169-178. doi:10.5455/ijamd.161640 
Parker, J. S., Schlegel, P., Doohan, D., \& LeJeune, J. T. (2016). Understanding perceptions of fresh produce safety and barriers to Good Agricultural Practices (GAP) use among Amish growers in the Holmes County Settlement of Ohio. Journal of Agriculture, Food Systems, and Community Development, 6(3), 37-59. doi:10.5304/ jafscd.2016.063.006

Pohekar, S. D., \& Ramachandran, M. (2004). Application of multi-criteria decision making to sustainable energy planning-A review. Renewable \& Sustainable Energy Reviews, 8(4), 365-381. doi:10.1016/j.rser.2003.12.007

Pradhan, P. L. (2017). Proposed Heuristics Model Optimizing the Risk on RTS. International Journal of System Dynamics Applications, 6(2), 31-51. doi:10.4018/IJSDA.2017040102

Reed, D. B., Browning, S. R., Westneat, S. C., \& Kidd, P. S. (2006). Personal Protective Equipment Use and Safety Behaviors Among Farm Adolescents: Gender Differences and Predictors of Work Practices. The Journal of Rural Health, 22(4), 314-320. doi:10.1111/j.1748-0361.2006.00052.x PMID:17010028

Rostami, F., Afshari, M., Rostami-Moez, M., Assari, M. J., \& Soltanian, A. R. (2019). Knowledge, attitude, and practice of pesticides use among agricultural workers. Indian Journal of Occupational and Environmental Medicine, 23(1), 42-47. doi:10.4103/ijoem.IJOEM_153_18 PMID:31040589

Sathaye, J. A., Najam, C., Cocklin, T., Heller, F., Lecocq, J., Llanes-Regueiro, J., ... Winkler. (2007). Sustainable development and mitigation. In Climate change 2007: Mitigation Contribution of working group iii to the fourth assessment report of the intergovernmental panel on climate change. Cambridge University Press. Retrieved on October 292019 from http://wwwipccch/pdf/assessmentreport/ar4/wg3/ar4-wg3-chapter12.pdf

Scheinberg, J. A., Radhakrishna, R., Campbell, J. A., \& Cutter, C. N. (2018). A Comprehensive Needs Assessment of Food Safety Practices of Farmers' Market Vendors in Pennsylvania Using Direct Concealed Observations, Self-reported Surveys, and State Sanitarian Surveys. Food Protection Trends, 38(6), 421-439.

Shukla, O. J., Jangid, V., Soni, G., \& Kumar, R. (2019). Grey Based Decision Making for Evaluating Sustainable Performance of Indian Marble Industries. International Journal of System Dynamics Applications, 8(2), 1-18. doi:10.4018/IJSDA.2019040101

Smil, V. (2001). Enriching the Earth: Fritz Haber, Cartosch, and the Transformation of World Food Production. MIT Press.

Sulewski, P., Kłoczko-Gajewska, A., \& Sroka, W. (2018). Relations between Agri-Environmental, Economic and Social Dimensions of Farms' Sustainability. Sustainability, 10(12), 4629. doi:10.3390/su10124629

Sydorovych, O., \& Wossink, A. (2007). Assessing Sustainability of Agricultural Systems: Evidence from a Conjoint Choice Survey In 2007 Annual Meeting. Southern Agricultural Economics Association.

Tashi, S., \& Wangchuk, K. (2016). Prospects of Organic Farming in Bhutan: A SWOT Analysis. Advances in Agriculture. 10.1155/2016/1717352

Tetemke, D. A. K., Tefera, Y., Sharma, H. R., \& Worku, W. (2014). Knowledge and practices regarding safety information among textile workers in Adwa town, Ethiopia. Sci Postprint, l(1), 5.

Tilman, D., Cassman, K. G., Matson, A., Naylor, R., \& Polasky, S. (2002). Agricultural sustainability and intensive production practices. Nature, 418(6898), 671-677. doi:10.1038/nature01014 PMID:12167873

Tracey, S., \& Anne, B. (2008). OECD Insights Sustainable Development Linking Economy, Society, Environment: Linking Economy, Society, Environment. OECD Publishing. Retrieved on October 302019 from http:// wwwworldresourcesforumorg/files/file/Full\%20book.pdf

Turral, H., Burke, J. J., \& Faurès, J. M. (2011). Climate change, water and food security. Food and Agriculture Organization of the United Nations.

Van Calker, K. J., Berentsen, P. B. M., Giesen, G. W. J., \& Huirne, R. B. M. (2008). Maximising sustainability of Dutch dairy farming systems for different stakeholders: A modeling approach. Ecological Economics, 65(2), 407-419. doi:10.1016/j.ecolecon.2007.07.010

WHO. (1996). The WHO recommended classification of pesticides by hazard and guidelines to classification. WHO/PCS/963. World Health Organization, International Programme on Chemical Safety (IPCS). 
Zarbakhshnia, N., Soleimani, H., \& Ghaderi, H. (2018). Sustainable third-party reverse logistics provider evaluation and selection using fuzzy SWARA and developed fuzzy COPRAS in the presence of risk criteria. Applied Soft Computing, 65, 307-319. doi:10.1016/j.asoc.2018.01.023

Zeeshan, M., Shah, H., Durrani, Y., Ayub, M., Jan, Z., \& Shah, M. (2017). A Questionnaire-Based Survey on Food Safety Knowledge during Food-Handling and Food Preparation Practices among University Students. $J$ Clin Nutr Diet, 3(2), 18. doi:10.4172/2472-1921.100052

Zelinka, D., \& Amadei, B. (2019). A Systems Approach for Modeling Interactions Among the Sustainable Development Goals Part 2: System Dynamics. International Journal of System Dynamics Applications, 8(1), 41-59. doi:10.4018/IJSDA.2019010103

A. K. Sahoo $(P h D)$ is the Professor and Director in the school of mechanical engineering, Kalinga institute of industrial technoy (KIIT), Deemed to be University, Bhubaneswar, India and he has published more than 100 articles in reputed journals as well as conferences with Google scholar research citation of More than 1000 with $h$ index 15 as per Scopus. Actively engaged in research on metal Machining and Machinability studies, optimization and modelling, multicriteria decision making, scheduling, etc. Recipient of best staff award from KIIT and outstanding reviewer award from Elsevier. 